\title{
BEM COMUM E COMUNIDADE: ALGUNS FUNDAMENTOS DA POLÍTICA MEDIEVAL ITALIANA (SÉCULOS XIII-XIV)
}

Felipe Augusto Ribeiro ${ }^{1}$

\section{Introdução}

Falar de política na "Idade Média" não é simples. Primeiramente porque a historiografia negou-lhe, durante muito tempo, esta categoria, já que só compreendia os objetos políticos na dimensão do Estado Moderno. De fato, Joseph Morsel $^{2}$ nos lembra que as diferenças entre a nossa realidade, o nosso mundo, contemporâneo, e o mundo medieval são tão grandes que deveríamos olhar para ele como um mundo completamente estranho e, para isso, deveríamos lançar sobre ela um olhar etnográfico, como o de Pierre Clastres ${ }^{3}$ e tantos outros antropólogos, a fim de nos despojarmos de quaisquer categorias pré-concebidas que carreguemos conosco e que eventualmente nos levam a tecer avaliações anacrônicas sobre aquele período. Porém, cremos que não se deva ir tão longe: não se trata, também, de encarar os homens do passado como alienígenas; se aceitamos a premissa, ela própria antropológica, de que sempre há uma política (qualquer que seja ela) em toda sociedade - porque a política é, ontologicamente, a maneira que os homens desenvolvem de se relacionar publicamente uns com os outros - a pergunta que deveríamos fazer não é "teve a Idade Média uma política?" e sim "que política teve a Idade Média?".

A ausência de um Estado como o moderno no período anterior ao século XVI nos obrigaria a pensá-lo com a categoria da Sociedade. Ela forçaria a deslocar o político para outros espaços, outras instituições, outras lógicas. Se há política na Idade Média e ela não está no Estado, se ela está num locus muito mais amplo e difícil de cercar como a Sociedade, seria preciso aguçar o olhar e verificar que diferenças isso implicaria. Uma discussão inesgotável, mas também inescapável.

Para Hannah Arendt ${ }^{4}$, definir o político e as demais categorias que em torno dele orbitam é uma preocupação nossa porque a Modernidade, ao romper com o passado $e$ a transcendentalidade, perdeu de vista o que o fundamenta e significa. Para Claude Lefort $^{5}$, o político não preexiste à sua formulação; é uma autorrepresentação que a Sociedade faz de si mesma. Na Modernidade, sem uma metafísica que referencie essa

${ }^{1}$ Doutorando em História e Culturas Políticas pela Universidade Federal de Minas Gerais (UFMG). Pesquisador do Laboratório de Estudos Medievais (LEME). E-mail: <felipeaur@gmail.com>.

${ }^{2}$ MORSEL, Joseph. L'Histoire (du Moyen Âge) est um sport de combat: réflexions sur les finalités de l'Histoire du Moyen Âge destinées à une société dans laquelle même les étudiants d'Histoire s'interrogent. Paris: LAMOP, 2007. Disponivel em: https://halshs.archives-ouvertes.fr/halshs-00290183. Acesso em: 13 jul. 2017.

${ }^{3}$ CLASTRES, Pierre. A sociedade contra o Estado: pesquisas de antropologia política. São Paulo: Cosac Naify, 2012.

${ }^{4}$ ARENDT, Hannah. Entre o passado e o futuro. São Paulo: Perspectiva, 2005.

${ }^{5}$ LEFORT, Claude. Pensando o político: ensaios sobre democracia, revolução e liberdade. Rio de Janeiro: Paz e Terra, 1991. 
representação, a Sociedade sofre com a sua incapacidade de forjar outra imagem do político e, daí, compreendê-lo e experimentá-lo.

A autora nos lembra: a experiência do sujeito social é feita no contato que ele mantém com a sua representação. O ser é experimentado na aparência. Lefort frisa que essa experiência é histórica, isto é, apreendida no tempo e no espaço. É preciso, portanto, circunscrevê-la num recorte que permita perceber o momento de sua fundação, porque é ali que a Sociedade dá à luz sua representação. Mas, conforme Arendt, as fundações, mesmo irrepetíveis, estão em constante atualização; não são estanques no tempo. Um bom exemplo disso nos deu Iacopo de Varazze (12281298), que abordaremos adiante: o bispo de Gênova (re)fundou a sua cidade sobre a dupla autoridade de Roma e de Cristo. Primeiro afirmou, lembrando o Antigo Testamento: "de fato, toda cidade tem dois construtores: um principal, que em verdade é o próprio Deus, e outro secundário, isto é, algum homem terreno". Em seguida teceu uma nova linhagem de heróis fundadores que vinculam o passado de Gênova a Roma: "depois, com o passar do tempo, construída que foi Babilônia, muitos outros construíram cidades, como Nino que construiu Nínive, e muitos outros depois dele. Muitos destes, entre os quais estava Giano, chegaram navegando à Itália, onde fundaram muitíssimas cidades. Porém, deve-se notar que existiram três Gianos: o primeiro é Giano, que do Oriente veio para a Itália e aqui, num primeiro momento, reinou. O segundo é um príncipe que foi cidadão de Tróia e que depois da destruição de Tróia chegou à Itália. O terceiro é o rei dos Epirotos, que veio a Roma e que, depois de sua morte, os Romanos o elevaram à categoria de deus e o veneraram como a um deus. Prossigamos, com ordem e brevemente, com a história destes três

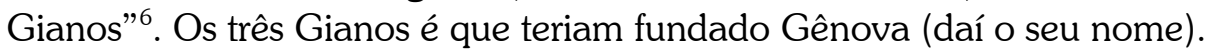

Assim, fazer um recorte temporal e perceber os laços de continuidade que cada presente mantém com o passado pode nos possibilitar vislumbrar a fundação (no tempo) e a auto representação de uma Sociedade. É esse exercício que faremos neste artigo: procurar entender o político num dado momento e lugar históricos - quais sejam: as cidades centro-setentrionais da Itália medieval (com ênfase nos séculos XIIIXIV). Para entender a política medieval, tentaremos estabelecer como ponto de partida a compreensão de algumas imagens que os homens medievais construíram nesse campo. Tentaremos iluminar justamente a representação que esse mundo fez de si próprio, recorrendo a termos significantes dos discursos que ele forjou sobre si: Pierre Bourdieu ${ }^{7}$, para quem a linguagem, sob a aparência de descrever, prescreve i.e., propõe -, explica a funcionalidade de analisar os discursos produzidos pelos agentes históricos encontra justificativa: a política é feita justamente no encontro entre o que é proposto na ação de um ator e o que é esperado no anseio de outro. A política cumpre o seu papel estruturante quando a ação corresponde à expectativa, à representação. Em Arendt ${ }^{8}$ está patente o papel significante do discurso sobre a ação, essa capacidade criadora e instituinte da realidade, e, para Bourdieu:

\footnotetext{
${ }^{6}$ IACOPO DE VARAZZE. Chronica Civitatis Ianuensis ab origine urbis usque ad annum MCCXCVII. Editado por Stefania Bertini Guidetti. Gênova: ECIG, 1995. [Tradução de André Luis Pereira Miatello]. p. 340-342.

7 BOURDIEU, Pierre. "Descrever e prescrever: as condições de possibilidade e os limites da eficácia política". In: A economia das trocas linguísticas: o que falar quer dizer. São Paulo: USP, 1998.

${ }^{8}$ ARENDT, Hannah. A condição humana. Rio de Janeiro: Forense Universitária, 2000.
} 
a ação propriamente política é possível porque os agentes, por fazerem parte do mundo social, têm um conhecimento (mais ou menos adequado) desse mundo, podendo-se então agir sobre o mundo social agindo-se sobre o conhecimento que os agentes têm dele. Esta ação tem como objetivo produzir e impor representações (mentais, verbais, gráficas ou teatrais) do mundo social capazes de agir sobre esse mundo, agindo sobre as representações dos agentes a seu respeito. Ou melhor, tal ação visa fazer ou desfazer os grupos - e ao mesmo tempo, as ações coletivas que esses grupos podem encetar para transformar o mundo social conforme seus interesses - produzindo, reproduzindo ou destruindo as representações que tornam visíveis esses grupos perante eles mesmos e perante os demais ${ }^{9}$.

Especifiquemos: as imagens de que falamos aqui não são ícones, pictografias; trataremos de imagens conceituais, verbais. Pretenderemos, especificamente, compreender nas fontes que escolhemos dois conceitos que nos parecem centrais para compreender o mundo e o pensamento político baixo-medieval: bem comum e comunidade.

\section{A fundação do corpo social}

Analisar os nomes que os medievais usaram para falar de suas coisas é indispensáve ${ }^{10}$. A presença do termo societas no vocabulário de época poderia nos autorizar a falar literalmente em uma sociedade, porém ele não diz respeito a essa categoria; como bem observa Arendt" ${ }^{11}$, tal palavra denotava meramente "certa aliança entre pessoas para um fim específico". Uma acepção inicialmente política embora limitada, não-universal, e por isso a traduzimos com a inicial minúscula - mas que em seguida se despolitiza, ao "economicizar-se" (ou seja, fundamentar-se na economia): societas indicava um grupo, frequentemente familiar, reunido em torno de uma atividade econômica, como uma corporação de ofício ou um feudo, por exemplo. Não era, pois, um termo de cunho cívico, relativo à política, como um todo.

Essa associação não é o que estamos entendendo por Sociedade porque ela tem caráter econômico, não político. Mas aqui é decisivo fazer uma nuance. Michel Foucault ${ }^{12}$ nos oferece uma visão parecida com a de Arendt: também para ele a societas é uma agremiação de cunho econômico. Entretanto, não é isso que a torna uma coletividade a-política, meramente doméstica, porque a economia foi ela

\footnotetext{
${ }^{9}$ BOURDIEU, A economia das trocas linguísticas... p. 347.

${ }^{10}$ Comprometemo-nos, portanto, com uma história conceitual do político, conforme ROSANVALLON, Pierre. "Por uma história conceitual do político". Revista Brasileira de História. v. 15. n. 30. São Paulo: [s.l.], 1995.

${ }^{11}$ ARENDT, A condição humana... p. 32.

${ }^{12}$ FOUCAULT, Michel. Segurança, território, população. Curso dado no Collège de France (1977-1978). São Paulo: Martins Fontes, 2008.
} 
própria, desde muito cedo, ainda na antiguidade, ampliada para além da casa (o oikos) e tornada um fazer político: não à toa autoridades como Aristóteles e Cícero desenharam o bom homem político como o bom dominus, o bom pater familias. Economia e política, pois, não se separam. A tese da oikonomia como uma atividade inerente ao político, responsável por ordenar as coisas com vista a uma finalidade que passa do bem familiar para o bem comum, cívico - é desenvolvida em detalhes por um discípulo de Foucault, Giorgio Agamben ${ }^{13}$. Destarte, o que define a societas como uma entidade não-política não é o seu caráter econômico, mas sim o seu caráter privado.

Para indicar a essa dimensão pública da Sociedade os homens medievais usaram outra palavra, retirada do léxico romano: civitas. Este é o termo que indica o que nós chamaríamos de Sociedade. A tradução literal do termo lhe faz jus: "cidade"; não há agremiação humana mais pública que a cidade. Arendt, infelizmente, contempla em sua obra a noção de civitas para os romanos, não para os medievais. Porém, o termo civitas nunca deixou de ser usado, embora em certos recortes espaciais e temporais ela possa não aparecer, já que existem gradações, digamos, no caráter público das associações humanas: nem todas elas gozam dos plenos direitos que uma civitas pode evocar para si, conquanto não deixem, por isso, de serem públicas; é o caso de coletividades como as vilas (villae), os castelos (castra) e as plebes (plebes), unidades sociais que fizeram parte de todo o ocidente medieval e foram importantes, enquanto eixos de organização territorial e administrativa, especialmente nos momentos $e$ lugares onde estavam ausentes ou que se recusavam as jurisdições citadinas.

De toda forma, civitas sempre fez parte da linguagem política medieval, sempre designando cidades, os corpos políticos por excelência, como se percebe desde o uso feito por Agostinho de Hipona (354-430) na fórmula "civitate dei"14 (a ideia de uma "cidade santa" já estava presente no capítulo 11 do livro do Apocalipse). São muitas as menções ao termo também em Gregório Magno (540-604), por exemplo, que o emprega para se referir a Perugia ${ }^{15}$. O uso dessa palavra, que é uma verdadeira ideia política, foi ininterrupto até, pelo menos, o século XIII: os estatutos da cidade de Ferrara, em 1288, falam de uma "civitatis ferrarie"16; os de Milão, em 1351, de "civitatis, comitatus et districtus Mediolani"17, i.e., a cidade, o condado e o distrito de Milão (englobando, portanto, a área rural que em torno da cidade orbita); e, novamente, o arcebispo e pregador de Gênova, Iacopo de Varazze, em sua narrativa histórica da Chronica Civitatis Ianuensis ab origine urbis usque ad annum MCCXCVII, que narra de forma épica a trajetória de sua cidade, de sua fundação até 1292.

Nota-se aí, é importante frisar, que a noção de "cidade" contida em civitas não é a de um espaço físico, urbano: a isso se chamava urbs, conforme o próprio Gregório

\footnotetext{
${ }^{13}$ AGAMBEN, Giorgio. O reino e a glória: uma genealogia teológica da economia e do governo. São Paulo: Boitempo, 2011.

${ }^{14}$ AGOSTINHO DE HIPONA. De civitate dei. [S.l.: s.n.], 1825.

${ }^{15}$ GREGÓRIO MAGNO. Libri dialogorum IV. In: Storie di santi e di diavoli (Dialoghi). v.2. Livro III, 13. Editado por Manlio Simonetti. Turim: Fondazione Lorenzo Valla, 2006. [Tradução de André Luis Pereira Miatello]. p. 48.

${ }^{16}$ STATUTI di Ferrara dell'anno 1288. In: MONUMENTI istorici pertinenti alle pprovincie dela Romagna. Serie prima. Editado pelo Conde Cammillo Laderchi. Bolonha: Tipografia Régia, 1864. p. 3.

${ }^{17}$ STATUTA iurisdictionum mediolani saeculo XIV. Editado por Antonio Ceruti. Bolonha: Tipografia Régia, 1869.
} 
Magno atesta: "[...] o exército dos Godos cerceou aquela urbe [urbs] por sete anos contínuos" ${ }^{18}$. Falando de cerco, Gregório dava a entender, aqui, que os invasores permaneceram perante as muralhas da cidade, à sua estrutura física. A cidade se referia, bem entendido, a uma comunidade. Bonvesin de la Riva (1240-1315), retórico milanês que escreve em 1288 um panegírico para elogiar a sua cidade, nos mostra quais elementos compõem uma civitas excelente como Milão:

Nem admire disso, porque Miláo precede todas as cidades. Considere-se, pois, o condado e a sua diocese, o lugar $e$ as casas, a qualidade $e$ a quantidade de seus habitantes. Considere-se também a fertilidade $e$ a abundância de todos os bens disponíveis ao uso comum dos homens. Considere-se a força, a fidelidade constante, a liberdade louvável, a riqueza das magistraturas; ficará claro que Milão é, entre todas as demais cidades, como o sol entre os corpos celestes ${ }^{19}$.

A civitas é, portanto, composta de homens de qualidade, de liberdade, de força, de boas magistraturas. Cremos que esse trecho demonstra bem o caráter público e político de civitas presente mesmo entre os medievais tardios.

Outro termo com acepção política que ocorre com frequência na literatura medieval é communitas. Como observa Patrick Gilli ${ }^{20}$, communitas começa a ser usada tardiamente, às vezes em substituição a civitas; os termos parecem intercambiáveis. A tradução literal nos daria "comunidade", mas dela também deriva "comuna", que é como, ainda mais tardiamente, algumas cidades autônomas - na Itália, no midi francês e em Flandres - ficaram conhecidas: a historiografia as chama de repúblicas ou "cidades-estado". O termo res publica aparece, aliás, algumas vezes, na linguagem da época, para qualificar essas cidades, como mostram Quentin Skinner ${ }^{21}$ e Mario Ascheri ${ }^{22}$ - embora as repúblicas citadinas não se compreendessem como organismos à parte da república maior que constituía o mundo romanizado. Communitas nos dá o significado de uma união, unidade (unitas) feita em prol de alguma coisa, conforme o prefixo "co-" indicia. Assim como a societas, a communitas se caracteriza pela finalidade, tanto quanto pela unidade. Porém, à diferença dela, a finalidade da communitas não é econômica, mas política, porque pública e universalista, como se verá adiante.

Compreenderíamos melhor essa unidade através da metáfora do corpo: ela se compõe de membros distintos, porém isonômicos, e todos existem para o mesmo fim e conforme a mesma natureza. Por isso falamos aqui em um "corpo social". "Corpo" porque é essa a analogia empregada pelos próprios medievais, e "social" porque ele

${ }^{18}$ GREGÓRIO MAGNO. Libri dialogorum... p. 48.

${ }^{19}$ BONVESIN DA LA RIVA. De magnalibus Mediolani. Editado por Giuseppe Pontiggia e Maria Corti. Milão: Bompiani, 1974. [Tradução de André Luis Pereira Miatello]. p. 24.

${ }^{20}$ GILLI, Patrick. Cidades e sociedades urbanas na Itália medieval (séculos XII-XIV). Campinas: Unicamp; Belo Horizonte: UFMG, 2011.

${ }^{21}$ SKINNER, Quentin. As fundações do pensamento político moderno. São Paulo: Companhia das Letras, 1996.

${ }^{22}$ ASCHERI, Mario. "La città-Stato italiana: uma vicenda storica inconclusa?" KOS. CCXLI (ottobre 2005). Disponível em: http://www.rm.unina.it/. Acesso em: 8 jul 2017. p. 40-45. 
diz respeito a todos os indivíduos. Consequentemente, essa expressão diz respeito também a todos os aspectos da vida humana, à vida coletiva, enfim, àquela a que se refere Arendt ${ }^{23}$. A sociabilidade, afinal, é uma vasta característica que diz respeito mesmo a outros animais (por isso não diferencia o ser humano), e sua amplitude é grande o suficiente para abarcar a universalidade das coisas a que nos remetemos quando utilizamos uma categoria como sociedade.

\section{Do corpo social ao corpo político}

O enorme conteúdo do termo "social", todavia, gera confusões e em nada contribui para que se entenda o sentido de comunidade. Mais ainda: o político resta sem lugar nessa conceituação indefinida. Mas não é à toa: como novamente nota bem Arendt $^{24}$, não há tradução latina para o grego politikos, senão o próprio socialis, que opera um verdadeiro descolamento do conceito de sua origem, a polis, para aplicá-lo a todo o gênero humano: é aí que a ideia perde seus contornos reconhecíveis. $\mathrm{E}$, de fato, não se encontra um termo equivalente na linguagem medieval; nela, a ideia é a de que o homem é naturalmente sociável, não político.

É preciso, portanto, recorrer a outras referências para falar do político; não encontraremos uma fonte própria do medievo. O importante aqui é notar como o corpo que é social se torna um corpo político, isto é, uma comunidade.

\section{A inerência da pluralidade humana}

$\mathrm{Na}$ interpretação de $\mathrm{Arend}^{25}$, Deus criou o homem na pluralidade: fê-los diferentes entre si, e não fez um só. Uma pluralidade paradoxal, é verdade: "o homem" diz respeito a todo o gênero humano, mas também a cada indivíduo singular. A distinção é feita na igualdade: os homens distinguem-se entre si, mas não deixam, por isso, de serem todos homens. Segundo a própria autora, porém, a interpretação cristã do mito criacionista é distinta: o que marca o homem é a unicidade.

Numa visão arendtiana, portanto, a pluralidade faz parte da condição humana. Por sua vez, esta faz parte da condição de existência do político: é porque são plurais que os homens podem viver em conjunto. É porque são distintos que precisam e podem se relacionar.

A compreensão da pluralidade humana requer o entendimento de outros dois pontos cruciais do pensamento arendtiano: a igualdade e a ação. Realmente, é nesses dois elementos (dentre outros), que a autora centra suas teses; a pluralidade é objeto de menor conceituação em sua reflexão, porque, para ela, é algo dado, pressuposto. Não nos ateremos a esse problema, porém.

\section{O antagonismo como fundamento do político}

\footnotetext{
${ }^{23}$ ARENDT, A condição humana... p. 31-32.

${ }^{24}$ ARENDT, A condição humana..., p. 12.

${ }^{25}$ ARENDT, A condição humana..., p. 16.
} 
Enquanto premissa, a pluralidade serve de base para que Arendt conceba a vida social, em conjunto, como uma possibilidade franca para a divergência e o antagonismo. O raciocínio é claro: se os homens são plurais e distintos entre si, significa que a vida social deve dar vazão a essa distinção, deve manifestar-se ela também na de forma plural. Engajada no enfrentamento do trauma que foram as experiências totalitárias do século XX - experiências que, em sua leitura, suprimiram de todas as formas a condição humana -, essa possibilidade lhe é cara demais. A oportunidade para que o homem se distinga daqueles que o cercam - e se oponha a eles, inclusive - e possa escapar ao caminho que o seu grupo segue representa, para a autora, a possibilidade mesma de resistência e de combate a fenômenos brutais como o do totalitarismo.

No entanto, parece estar certo para a autora que valorizar a pluralidade não significa postular que o dissenso é a chave da vida social. Trata-se apenas de marcá-lo enquanto constitutivo do político. De maneira que o antagonismo limita-se, no horizonte de ideias da pensadora, a outra premissa do político, uma consequência da pluralidade. Tanto que ela também não produz uma definição satisfatória do que seja ele. Talvez porque soubesse que essa definição já tivesse sido claramente feita, nos anos 20 (e Arendt escreve nos anos 50 e 60), por Carl Schmitt. É a ele, então, que devemos recorrer para sintetizar a noção de antagonismo.

Para Schmitt, o fundamento do político é a contradição, isso que estamos chamando de antagonismo. Nele está implícita a pluralidade, é claro. Mas para Schmitt uma faceta desse pluralismo e logo, do antagonismo, é decisiva na definição do político: a distinção amigo-inimigo ${ }^{26}$. A relação humana na forma do conflito, do embate, é que constitui verdadeiramente o político, que o define de maneira última, embora não o explique, porque nem toda relação política se estabelece entre amigos $e$ inimigos. Mas é só a essa dicotomia que o político pode ser válida e seguramente reduzido; é ela a sua engrenagem.

Enquanto não demonstra preocupação suficiente com a figura do amigo, Schmitt nos oferece, por outro lado, uma definição assaz precisa do que seja o "inimigo":

o inimigo, portanto, não é o concorrente ou adversário em geral. $\mathrm{O}$ inimigo também não é o adversário particular, que odiamos por sentimentos de antipatia. Inimigo é um conjunto de homens, pelo menos eventualmente, isto é, segundo a possibilidade real, combatente, que se contrapõe a um conjunto semelhante. Inimigo é apenas o inimigo público, pois tudo que se refere a tal conjunto de homens, especialmente a um povo inteiro, torna-se, por isto, público. Inimigo é hostis, e não inimicus no sentido lato; polémios, não ekhthrós ${ }^{27}$.

O inimigo não é um mero discordante; é um opositor hostil. A inimizade real não se limita a sua própria constatação; ela se traduz obrigatoriamente em luta. E essa luta

${ }^{26}$ SCHMITT, Carl. O conceito do político. Petrópolis: Vozes, 1992, p. 51-53.

${ }^{27}$ SCHMITT, O conceito do político..., p. 55. 
só pode se inscrever no público (jamais no privado): por isso (e só assim) ela é política.

Em Schmitt, o antagonismo não é mera oposição partidária nem esgota o político $^{28}$. Mas é a eterna iminência da luta, uma das formas de realização do antagonismo e da pluralidade, da distinção inter-humana, que leva os homens a viver juntos, a formar uma sociedade, a construir um mundo político ${ }^{29}$. Entretanto, vemos que ainda se mantém a confusão entre o que é político e o que é social. Vejamos, então, como podemos discernir uma coisa da outra.

A esse respeito, retornando ao recorte espaço-temporal que elegemos, um pacto de paz estabelecido em Assis, em 1203, é revelador. Após um ano de terrível guerra civil, a cidade consegue reconciliar os inimigos:

Em Assis houve certa desavença entre os homens bons e os homens do povo, e, durante esse tempo, foram destruídos castelos e casas. Nós, Iacopo, Tancredo de Ugão e Marangão, comissionados por esta Comuna para estabelecer a paz mútua entre os antes mencionados, para tais efeitos ordenamos: $[\ldots]^{30}$.

E mais que isso: após a reconciliação ela procurar eliminar a possibilidade de novos conflitos:

Quem quer que se oponha ao anteriormente acordado cairá nas penas da Comuna, pagando cem libras. Se não as tem, será submetido ao juízo dos cônsules. Se o povo não observar o acordado, deverá pagar mil libras aos homens bons. Se os homens bons não cumprirem, pagarão eles mil libras aos homens do povo ${ }^{31}$.

Decretamos que todos os danos e prejuízos ocasionados aos castelos mencionados sejam pagos por quem os provocou. $\mathrm{E}$ os que padeceram ou receberam os prejuízos, não podem devolvê-los com suas próprias mãos sobre as pessoas ou bens dos que os provocaram. Não poderão tampouco apresentar reclamação alguma na corte do Imperador ou na cúria Apostólica ou a algum de seus legados. Tampouco poderão pôr término ou obter os instrumentos de pacificação ratificados por esta comuna, tanto os já feitos como os que serão estabelecidos no futuro, sob pena de mil libras ${ }^{32}$.

${ }^{28}$ SCHMITT, O conceito do político..., p. 58-59.

${ }^{29}$ SCHMITT, O conceito do político..., p. 60-61.

30 TRATADO de paz entre los Buenos hombres y los hombres del Pueblo, em Asis. [S.l.: s.n., s.d]. Disponível em: http://franciscanos.net/document/tratado1.htm. Acesso em: 5 jul. 2013. [Tradução nossa].

${ }^{31}$ TRATADO...

32 TRATADO... 
Aqui fica claro uma ideia aventada tanto por Arendt quanto por Schmitt: embora a pluralidade esteja no fundamento da política, o seu desejo é converter essa pluralidade numa unidade: o ideal é que os inimigos se tornem amigos e não haja luta. O devir do plural é o uno, conforme testemunha uma bula do papa Inocêncio III (1161-1216), na ocasião do arbítrio de uma querela em Perugia, em citação literal da Epístola aos Efésios: "imitando os vestígios do Verdadeiro construtor da Paz, ele que é nossa paz, que de dois fez um só (Ef 2, 14)" "33.

Sintomático que "paz" e "unidade" andem tão juntas. É claro, tal proposição se assenta, sobretudo, no campo discursivo, porque na prática encontramos também uma outra faceta possível do conflito: a ordenadora, engendradora e não interruptora de laços sociais. É o caso, trabalhado por Andrea Zorzi ${ }^{34}$ (leitor de Schmitt) sobre a vendetta medieval, a vingança que visava a restituir, por direito, um dano causado por alguém e recobrar a normalidade, a equidade e a tranquilidade entre os membros litigiosos $e$, por fim, toda a comunidade, que evitava ser prejudicada por brigas particulares. A vendetta constituía uma violência redistributiva, não destrutiva, desde que fosse regulada e não causasse malefícios à cidade. Da mesma maneira, Pietro Costa $^{35}$ mostra como, em alguns casos, o dissenso era tolerado como necessário à vida política, desde que ele se apresentasse como maneira melhor do que o consenso para se alcançar o bem comum. Um exemplo é o pensamento do jurista Bartolo de Sassoferrato (1313-1357), que admitiu a fragmentação do corpo político em partidos divergentes, desde que eles servissem para se depor um tirano do poder. Ou seja, na prática, os homens medievais, como quaisquer outros, souberam em quais momentos era premente aceitar as divergências derivadas da pluralidade humana e entenderam que a única solução para evitar que elas fragmentassem o corpo cívico era absorvêlas, regrá-las, não exorcizá-las ou suprimi-las.

Um outro testemunho sobre a percepção medieval do conflito e do político nós temos no cronista Rolandino de Pádua (1200-1276). Narrando, em 1262, as inúmeras guerras que reviravam a região da Marca Trevisana, assim o escritor sintetizou o motivo original dos conflitos: "qualquer um pode imaginar que os nobres de Camposampiero, embora a mãe deles fosse irmã de Ezzelino II, não iriam esquecer aquela ofensa e trapaça que Ezzelino I fizera aos lhes roubar fraudulentamente o matrimônio com a senhora Cecília"36.

${ }^{33}$ INOCÊNCIO III. Veri pacifici vestigia [21 de setembro de 1214]. In: GILLI, Patrick \& THÉRY, Julien. Le gouvernement pontifical et l'Italie des villes au temps de la théocratie (fin XIIe-mi-XIVe s.). Montpellier: Presses Universitaires de la Méditerranée, 2010. [Tradução de André Luis Pereira Miatello]. p. 442.

${ }^{34}$ ZORZI, Andrea. "Fracta est civitas magna in tres partes": conflitto e costituzione nell'Italia comunale". Scienza e politica. v. 39. [S.1.: s.n.], 2008. Disponível em: https://scienzaepolitica.unibo.it/ article/download/2749/2146. Acesso em: 13 jul. 2017.

${ }^{35}$ COSTA, Pietro. Bonum commune e partialitates: il problema del conflitto nella cultura politico-giuridica medievale. In: Il Bene Comune: forme di governo e gerachie sociali nel Basso Medioevo. Atti del XLVIII Convegno storico internazionale. Todi: 9-12 ottobre 2011. Espoleto: Fondazione CISAM, 2012.

${ }^{36}$ ROLANDINO DE PÁDUA. Cronica in factis et circa facta Marchie trivixane. Editado por Flavio Fiorese. Turim: Fondazione Lorenzo Valla/Arnaldo Mondatore Editore: 2005. [Tradução de André Luis Pereira Miatello]. 
Sem mergulhar no caso desses conflitos, vemos que, para Rolandino, foi um ato injusto, cometido por um particular (Ezzelino I), o causador da discórdia. Esse ato fez toda a família Camposampiero opor-se, como inimiga, à linhagem de Ezzelino. Estava criada a polarização schmittiana e inaugurada a possibilidade perene do conflito. $\mathrm{E}$ assim o cronista apresenta o desfecho das guerras: como em Assis, um árbitro super partes foi delegado, instaurando a paz por meio da palavra (embora em Assis essa palavra tenha assumido a forma normativa de um pacto, enquanto em Pádua ela tenha tomado a forma prescritiva de uma exortação): "nós pedimos que dispenseis os vossos exércitos, por respeito a Deus, voltando cada um para a sua casa. Apresentai a vossa questão a nós e à comuna de Pádua e nós saberemos aquilo que for conforme à razão, dissiparemos as lutas e, com a ajuda de Deus, decidiremos segundo os devidos fins" 37 .

$\mathrm{O}$ árbitro exerce a política, a razão, contendo as paixões que levam à luta. E ele o faz em nome da comunidade: o árbitro é uma autoridade pública. A razão preside a comunidade, porque ela é quem produz o arbítrio e a justiça, que são as garantias mesmas de manutenção da comunidade.

\section{O político como modo (ou grau) do social}

Para Schmitt, o político não é um "âmbito próprio", mas um "grau" de intensidade da associação (ou dissociação) humana ${ }^{38}$. Isso significa que o político se forma numa polarização; o emprego do termo grau nos remete precisamente à ideia de uma tensão (aplicada numa corda, por exemplo), em que quanto maior a sua intensidade, maior o caráter político da relação humana. Daí que, se entendemos o social, conforme dissemos, efetivamente como um campo, o terreno amplíssimo da vida humana composto por posições de poder, relações de clientela, ações políticas, ordens sociais (conjuntos de regras, éticas e comportamentais, com certo grau de durabilidade), conflitos, interesses particulares e inúmeros outros elementos, podemos compreender o político como um grau (falando com Schmitt) do social, um modo de organização desse campo. O político é a forma que o social - inicialmente sem contornos, irreconhecível como um todo - assume num momento preciso, que é o do conflito, da luta. O conflito dá forma ao social.

A força do conflito - e, pois, do político - pode vir dos mais variados aspectos da vida humana: mesmo motivos a priori não-políticos se politizam ao virarem objetos de litígio. Ora, esses são os infinitos elementos dispersos pelo espaço amorfo do social. Pensando com a Física, podemos imaginar que o conflito, ao posicionar os inimigos nos dois polos da esfera social, cria entre eles uma diferença de potencial, já que os "combatentes" estão carregados de seus motivos (e quanto mais energia esses motivos tiverem ou despertarem, maior será a diferença de potencial), e desta diferença de potencial teremos um campo magnético, cuja força organizará, por atração e repulsão, os elementos à deriva na esfera, dando-lhes um arranjo que, evidentemente, dependerá da força que cada polo litigioso possui.

\footnotetext{
${ }^{37}$ ROLANDINO DE PÁDUA. Cronica in factis et circa facta Marchie trivixane...

${ }^{38}$ SCHMITT, O conceito do político... p. 64.
} 
Esta é uma maneira pela qual acreditamos ser possível passar da compreensão de um corpo social para a de um corpo político. $\mathrm{O}$ corpo se torna político à medida que em torno dos elementos sociais se estabelecem lutas que produzem relações políticas (ou seja, relações baseadas no par amigo-inimigo). Com justeza, faz mais sentido falar em corpo político, uma vez que, sendo amorfo o corpo social, só é possível apreender a sua existência quando ele se torna político e ganha forma.

Falávamos em communitas e dizíamos que ela denotava, nas comunas italianas dos séculos XIII e XIV, uma unidade política. Curioso aqui seria concluir, então, que na base dessa unidade está o conflito; parece paradoxal, porque o conflito é historicamente compreendido como desagregador. Conforme Arendt e Schmitt, porém, seria isso mesmo: para ambos a pluralidade e o antagonismo constituem o político, mesmo em sua dimensão unitária; há um caráter construtivo no conflito. Se o político está no público, o conflito também; se o conflito instaura o público-político, pode instaurar a comunidade.

\section{Do político à política}

Mas, antes de tudo, ainda resta uma confusão para desfazer: político ou política? Retornemos a Lefort ${ }^{39}$.

O conflito não pode acontecer na anomia, sob pena de que se converta em pura barbárie, em violência gratuita, desregrada e destrutiva. Ao contrário, a luta precisa de normas para se realizar. Efetivamente, só sob a égide da norma é que o conflito pode ser construtivo, i.e., político. O conflito desregulado é destrutivo do corpo social e não engendra o político.

O conflito precisa, portanto, ser racionalizado. Para Lefort, é precisamente à racionalização do conflito e do político que se dá o nome de política. Se o político é um modo do social, um modo das relações humanas, fundado pelo antagonismo, a política é a atividade humana de racionalização desse processo. A política é produto da faculdade humana, da razão. Vimos como os assisienses nomeiam árbitros para estabelecerem a paz entre os inimigos. Esses comissários "ordenam" uma série de decretos que visam a evitar o conflito, entre eles:

Quem tiver que sair desta cidade ou quem partiu nos tempos da guerra que a Comuna travou com os homens de Perugia, a não ser que seja campesino, para ser inimigo desta cidade $e$ que tiver feito algum mal a esta cidade, todos os seus bens serão tornados públicos. E os cidadãos desta cidade darão poder aos cônsules para que os castiguem. E se alguém se opuser à pena que deve padecer, ainda que insistentemente suplique diante do tribunal dos cônsules, que tais fugitivos não tenham mais direitos tanto dentro como fora da cidade.

Quando um cavaleiro ou outro homem qualquer de nossa cidade tiver de ser repatriado ou tiver de pagar alguma dívida

${ }^{39}$ LEFORT, Pensando o político... 
a outra cidade ou castelo, ou a outra pessoa fora de nossa jurisdição, nossos cidadãos estarão obrigados a repatriá-lo ${ }^{40}$.

Há uma gestão pública do conflito: isso é a política. Se o conflito se instaura no privado - são os cidadãos, "homens bons" $e$ "homens do povo", "cavaleiros" $e$ "campesinos" que brigam -, a paz se faz, ao contrário, por entidades nomeadas pela própria coletividade. A comunidade confere poder $e$ autoridade a essas pessoas públicas, para que elas exerçam a justiça, apliquem as leis e devolvam ao corpo político a normalidade, restituindo a ordem $e$ até as propriedades privadas.

Tal atividade se desempenha através de uma série de mecanismos: as instituições, as leis, os costumes, o discurso. Eles não só atribuem significados e sentidos ao político, mas também lhe garantem a concretização. Em termos de amplitude, a política é mais específica que o político e nele se inscreve. E como os homens, diversos, é que produzem a política, sociedades diversas configuram políticas diversas. Logo, a política é a forma particular que o político assume em cada sociedade; é a forma particular com que cada sociedade gerencia seus conflitos inerentes.

Nesta altura vale questionar, então: o que confere eficácia à política?

\section{O fundamento teológico da política}

A questão da eficácia da política é cara à filosofia do século XX. Para a maior parte dos filósofos contemporâneos, a política perdeu, desde a Modernidade, a sua eficácia por se separar da metafísica. Em Arendt ${ }^{41}$ encontramos ótima demonstração desse pensamento: ao romper com o passado (e mesmo com o futuro), o presente perdeu de vista o referencial de autoridade transcendental que garantia a eficácia da política.

Essa sensação de perda tem um motivo: o fundamento teológico da política. Não é à toa que Schmitt amparou a sua tese da soberania num decisionismo criacionista revestido com ares de sacralidade; o soberano schmittiano é divinizado, posto acima do corpo político. Arendt também se ressentiu falta de "experiências autênticas e incontestes" ${ }^{42}$ que reabilitassem a política na Modernidade. A questão, para ambos, era reatar os laços entre a teologia e a política, a fim de recuperar a eficácia desta.

É a própria Arendt ${ }^{43}$ quem nos explicita melhor o que é o fundamento teológico da política. Para ela, o modelo político mais eficaz é o autoritário ${ }^{44}$, piramidal, no qual a autoridade, fonte da eficácia, está situada acima do corpo político, onde pode

\footnotetext{
${ }^{40}$ TRATADO...

${ }^{41}$ ARENDT, Hannah. Entre o passado e o futuro...

${ }^{42}$ SCHMITT, Carl. Political theology: four chapters on the concept of sovereignty. Chicago: University Press, 2005. p. 127.

${ }^{43}$ ARENDT, Entre o passado e o futuro...

${ }^{44}$ Importante notar que essa constatação se faz sem nenhuma valoração: hesitamos em afirmar que Arendt preferia os regimes autoritários aos democráticos, por exemplo. Mais justo parece ser concluir que, embora a democracia seja o regime próprio de nosso tempo, falta a ele construir os fundamentos de sua própria eficácia, a fim de que ela não pereça frente a novos regimes autoritários, que frequentemente trazem consigo a violência como meio de execução da própria política, o que é absurdo para a filósofa. O modelo societário piramidal serve apenas para identificar o fundamento transcendente da política; na práxis do mundo terreno, a melhor sociedade, para Arendt, era democrática, horizontal, não vertical.
} 
permanecer inconteste e emanar seu poder do topo até as bases, fazendo convergir a pluralidade e propiciando uma estrutura sólida para o social. A analogia com a pirâmide faz sentido: uma figura geométrica das mais estáveis e que ainda reflete o fato de que muitos são os submetidos ao poder (a base da pirâmide), mas poucos são os seus usuários (o topo). Este é um modelo concernente à Roma Antiga, é verdade, mas, que, como Arendt mesmo demonstra, é traduzido pelos cristãos, os quais simplesmente substituem a autoridade da fundação de Roma pela autoridade da paixão de Cristo: os pais de Roma deixam de ser autoridade e cedem seu lugar para Deus. Aí esse fundamento autoritário da política se torna teológico.

A linguagem política corrente nos anos 300 e 400 nos oferece outros dois conceitos que atestam o assento teológico da política. De um lado, a ideia de corpus mysticum, presente já em Paulo, o Apóstolo, indica que não somente o corpo do rei, mas também o corpo político é duplo: físico e metafísico, mundano e divino; é o corpo do homem e o corpo de Cristo. No corpo místico, divino, está depositada a autoridade que confere ao corpo mundano a eficácia no exercício da política. De outro lado, a ideia do pontifex, o governante de corpos e/ou de almas, encarregado de estabelecer uma ponte entre o físico e o metafísico, o mundano e o transcendental, os homens e Deus. Uma ponte absolutamente necessária, sem a qual o que é terreno carece de toda eficácia. No entanto, os medievais, assim como os seus antecessores romanos, estiveram atentos à premência desse vínculo com o atemporal, garantindo, com ele, a preservação do político e da política, mesmo após a ruína de Roma.

\section{O fundamento antropológico da política}

Um outro fundamento da política merece também a nossa atenção: o antropológico. Se a teologia estabelece uma ligação com o transcendental, a antropologia mergulha na própria condição humana e destaca os elementos que dela emergem para balizar a política.

Impossível discutir essa questão sem começar por Agostinho. Sob o impacto do saque de Roma perpetrado pelo rei visigodo Alarico (375-410), em 410, a proposta agostiniana da Cidade de Deus anunciou aos homens duas coisas: 1) a cidade (civitas) terrena é perecível e deve-se buscar somente a cidade eterna; 2) a cidade terrena rui porque os homens pecam. A trajetória de vida de Agostinho marcou a sua convicção na pecabilidade irremediável do homem. Lendo Platão através do estoicismo ciceroniano, ele se preocupou com a vida interior do homem, a sua consciência; o diálogo do homem consigo mesmo ${ }^{45}$, o dois-em-um da vida contemplativa era, para ele, uma dialética eterna entre o bem e o mal, na forma do desencontro entre o querer e o poder. O homem podia até desejar o bem, mas fazia o mal, pecava. Essa era marca indelével do descenso, da transgressão original, ainda no Éden.

Retornando a Rolandino de Pádua, temos um atestado da moralidade subjacente ao político (porque subjacente ao conflito):

${ }^{45}$ Para Arendt (Entre o passado e o futuro... p. 16), Agostinho é deliberadamente um pensador da singularidade, não da pluralidade. 
Eis que quando essa senhora [Cecília] chegou na predita vila [de Sant'Andrea Oltre Muson], Geraldo de Camposampiero, seu sobrinho, se aproximou indevidamente de sua tia e com ela, que deveria ter tomado como esposa, passou a ter uma relação incestuosa - cuja licenciosidade vou omitir - e assim pôs fim ao desejo de seu coração. A partir dessa faísca, a chama da ofensa se ascendeu e, ardendo o fogo, toda a Marca agora está em guerra, submetida à destruição e ruína. Entre irmãos e parentes, entre cidadãos $e$ vizinhos foi semeada a cizânia, os ódios, os malfeitos, as rixas, as fraudes, as malícias e rapinas, as trapaças $e$ rivalidades, mortes $e$ inimizades capitais, segundo mostraremos adiante ${ }^{46}$.

Em Rolandino, foi a dupla paixão desmedida, carnal e pecadora (a vontade de vingança por ter sua prometida esposa, Cecília, roubada por Ezzelino I, e o desejo de deitar-se com ela) de Geraldo de Camposampiero que deu vazão à gigantesca ruína (na tinta exagerada do cronista) trevisana; parece que todo o mundo humano entrou em colapso, já que até a unidade primeira da sociedade, a família, desagregou-se. Toda a moral acabou a partir de um pecado original: em verdade, na narrativa é como se Ezzelino I, trapaceiro, cometesse o pecado adâmico e, a partir daí, toda ação humana tivesse sido marcada por esse mesmo pecado, qual seja, o da cobiça, da ambição, do desejo pelo proibido, pelo que é do outro.

Esta é a diferença crucial entre Agostinho e os estoicos. Se para estes o homem podia alcançar a perfeição extirpando de si os vícios, para aquele essa tarefa é absolutamente impossível. O máximo que se pode pretender é controlar os vícios. Para tanto, faz-se necessária a razão. É aí que a política entra: ela é necessária porque permite racionalizar a vida humana, submetendo os vícios e viabilizando a perfeição (que, no entanto, só virá após a morte, na cidade eterna). $\mathrm{E}$, se os vícios prejudicam a vida coletiva (afinal, arruinaram Roma), a política tem, portanto, o papel de evitar que eles a destruam; permanece o seu papel ordenador, conforme aventamos.

Essa elaboração assume em Agostinho, todavia, uma feição mais particular: é com ele que começa a ser gestada a noção medieval de governo. Vejamos como.

\section{A necessidade do governo}

Para esse propósito, Michel Senellart nos oferece uma profícua leitura de Agostinho: com ele que nasce uma reflexão específica sobre o governo, enquanto parte da política. Segundo Senellart, baseando-se em Cícero, Agostinho

opõe dois tipos de governo através da antítese regeredominari: um regrado pela disciplina e a benevolência, o outro arrastado pela violência e o gosto do luxo. E é nesse contexto que ele propõe a etimologia famosa, reges a regendo. Mas enquanto, em Cícero, o dever de regere,

\footnotetext{
${ }^{46}$ ROLANDINO DE PÁDUA. Cronica in factis et circa facta Marchie trivixane...
} 
associado ao nome do rei, aplicava-se à pessoa mesma do governante e a seus súditos, Agostinho faz que ele sofra uma dupla transformação. De um lado, limita-o ao governo de si: regere é dominar a própria carne. De outro, em relação aos súditos, explicita-o pelo termo corrigere: regere é então agir sobre a vida dos outros, corrigindo-os ${ }^{47}$.

O governo é, pois, na visão agostiniana, uma necessidade diante da pecabilidade humana. Ele existe para corrigir os homens, evitar que pequem. Esta é uma necessidade porque, sem tal correção, os vícios humanos destroem o político e o social. E note-se que o governante, antes de corrigir os súditos, deve corrigir a si mesmo.

Senellart observa que, em Agostinho, apesar da anunciada antítese, há um reconhecimento de que a dominação, ao contrário de opor-se ao governo, é necessária a ele: os homens precisam ser dominados para que dominem seus vícios (o governante domina os próprios vícios, em primeiro lugar, depois coage os súditos a dominarem, cada um, os seus vícios). O governo enquanto regime (regimen) é, propriamente, a doutrina do corpo, do desejo e da alma.

Mas a noção de governo tem também um outro aspecto. Gubernare é o ato do comandante que guia o navio até um porto seguro. Governo, portanto, para os medievais, tem também o sentido de direção, condução ${ }^{48}$. O governante conduz os homens pela via da retidão, afastando-os dos vícios. Para tanto, ele precisa estar atento a tudo e a todos, vigiá-los; precisa ser um episcopus, o sentinela no alto da torre, que tudo vê e tudo sabe $e^{49}$. A visão totalizante e individualizante é necessária à tarefa governativa de corrigir os vícios: por isso a noção do rei-pastor - personificada na figura do rei Davi, que conduz e cuida da coletividade e de cada indivíduo, particularmente, como de um rebanho - fez fortuna entre os medievais ${ }^{50}$.

O cronista Salimbene de Parma (1221-1290) nos permite vislumbrar a necessidade do governo. Citando o livro dos Provérbios, ele afirma: "[...] onde não há governante o povo perece e a salvação reside onde há muitos conselhos (Prov. XI)"51.

Sobre ambas as noções, regere e gubernare, pesa uma moralidade, um juízo do que é bom e do que é ruim. O mau governante é o que não rege (aplica o regime) a si mesmo nem a outrem, nem guia os súditos na retidão. O bom governo, por sua vez, é o que cumpre esse duplo papel de reger e conduzir. Tal direção governativa tem uma finalidade, naturalmente. Observemos qual pode ser ela.

${ }^{47}$ SENELLART, Michel. As artes de governar: do regimen medieval ao conceito de governo. São Paulo: Ed. 34, 2006.

${ }^{48}$ SENELLART, As artes de governar... p. 101.

${ }^{49}$ Esse era, de fato, o papel do bispo, epíscopo: "Assim Agostinho escreve, comentado a frase de São

Paulo, 'aquele que aspira ao cargo episcopal deseja uma nobre função'". SENELLART, As artes de governar..., p. 102.

${ }^{50}$ FOUCAULT, Michel. “'Omnes et singulatim': uma crítica da Razão política”. In: DA MOTTA, Manoel Barros (org.). Michel Foucault: estratégia, poder-saber. Coleção Ditos e Escritos IV. Rio de Janeiro: Forense Universitária, 2003

${ }^{51}$ SALIMBENE DE PARMA. Cronica. [S.1.]: Scalia-Rossi, 2007. n. 750-757. [Tradução de André Luis Pereira Miatello]. p. 751. 


\section{A finalidade da política}

Se antes de Agostinho o bom governo era a própria finalidade da política - exercer uma racionalização eficaz do político -, a partir dele o bom governo torna-se meio para se atingir outra finalidade. Entre os medievais, na definição do que seja essa finalidade, pesa outra vez a herança romana.

No mais célebre dos ufanistas da República Romana, Cícero, essa finalidade estava bem clara: era o bonum commune, o "bem comum". Uma finalidade moral, certamente. Um bem que dizia respeito à comunidade, a todos, à coletividade, à Sociedade. Mas que "bem" era esse? Para Cícero, era a própria República. A comunidade era o bem a que a política, na forma do governo, devia se dirigir. Ou seja: em Cícero, a comunidade tinha fim em si mesma; o seu métier era se perpetuar. É por isso que o senador exaltou os seus próprios feitos em prol da República: a glória do bom romano era acrescentar alguma coisa à pátria, contribuindo pra sua eternização. A ato político por excelência, para um romano, era atualizar a fundação de Roma.

Quanto aos medievais, porém, Agostinho inaugurou outra novidade. Na sua pena, o bem comum tornou-se a salvação, salus: a finalidade dos homens passou a ser a ascensão e o retorno para junto de Deus (por isso era necessário coagir os vícios), logo, ea a isso que a política e o governo deviam se prestar. E novamente conversamos com Rolandino de Pádua.

Ora, sabemos e lemos nos livros sagrados e profanos que muitos sábios tementes a Deus operaram o bem, tiveram consigo a justiça, viveram honrados nessa vida $e$, por seus méritos, receberam a vida eterna. Sabemos também que alguns tiranos, ao contrário, não tiveram nenhuma reverência para com Deus, vangloriando-se em sua malícia, fizeram o mal o quanto puderam, desprezaram a justiça, viveram de muitos roubos e terminaram a vida na tribulação; assim, foram enviados à geena, entregues à eterna danação, lacerados pelos flagelos dos demônios e pelos tormentos ${ }^{52}$.

Relato bastante visível da moralidade política. O bom governante, legítimo, observa Deus e age honradamente; o tirano não. Um alcança - e leva consigo a comunidade - o céu, o outro cai no inferno. Nenhuma novidade nessa antiga noção. Mas estamos aqui para destacar a sua permanência e, mais que isso, indicar como os medievais se apropriaram dela para expressar discursivamente suas experiências políticas. Uma apropriação repleta de sentido: esse trecho é o que Rolandino diz ter registrado do discurso que o bispo Geraldo, indicado pela Comuna de Pádua (uma das vítimas dessa luta aristocrática), fez aos exércitos de Ezzelino, no intuito de pacificá-los. Mas Rolandino deixa transparecer, ao longo da crônica, que toma o partido dos Camposampiero: ele, de fato, estrutura a narrativa em torno de Ezzelino para enfatizar a sua tirania. Por isso esse coloca um discurso sobre a malícia, a justiça

${ }^{52}$ ROLANDINO DE PÁDUA. Cronica in factis et circa facta Marchie trivixane... 
e o respeito a Deus na boca do bispo: são essas as características que ele vê no tirânico Ezzelino. Ao passo que, no registro do discurso feito às tropas dos Camposampiero, Geraldo apenas pede que eles não lutem contra a própria mãe (irmã de Ezzelino), sem nenhum qualificativo moral. Rolandino ainda faz com que Geraldo assevere: "a misericórdia [do tirano] e a verdade [dos Camposampiero] se encontraram" 53 , posicionando Ezzelino não só como inimigo dos Camposampiero, mas de toda a comunidade paduana.

O deslocamento de sentido é patente: se, em Cícero, a finalidade da política está no mundo e é a própria comunidade terrena, em Agostinho ela está no além, no transcendente, e não é mais a comunidade mundana, mas uma outra, metafísica (como está claro no livro do Apocalipse, capítulo 21). Não que os medievais percam de vista a dimensão de busca pela excelência e de reprodução da comunidade. Nesse sentido, o pacto assisiense é novamente revelador da dimensão prática e na permanência dessa busca:

Todos os homens de Assis estarão habitualmente obrigados à mútua ajuda com o fim de preservar todos os seus bens, todas as suas coisas e direitos, costumes e propriedades que atualmente possuem $e$ todas as que, no futuro, possam adquirir, por direito ou por uso, aqui ou em outro lugar, sempre que seja de boa fé e sem fraude $e^{54}$.

A comuna de Assis se esforçou em afirmar que os cidadãos deviam zelar pela coletividade, e não destruí-la, como haviam feito. Preservando o todo, estariam preservadas as partes. A comunidade se fazia em prol disso. III:

Uma expressão mais pragmática do bem comum terreno se encontra em Inocêncio

Que a coleta ou muttita não seja feita a menos que se sigam quatro razões, quais sejam: para o serviço da Igreja Romana, do Povo Romano, do imperador ou de seus embaixadores e quando o Povo Perusino travar guerra de acordo com a vontade comum; e quando isso acontecer, a coleta seja feita fielmente por paróquia ou capela, de modo que em cada paróquia elejam-se duas pessoas que, após prestarem juramento, façam a coleta diligentemente, sem excluir ninguém por razão de amizade, consanguinidade ou outro motivo fraudulento; [...] Que a coleta ou muttita não seja feita até que reste alguma coisa do tesouro comum; e se essa quantia não for suficiente para o sustento dos cavalos, então, faça-se a coleta ou muttita ${ }^{55}$.

\footnotetext{
${ }^{53}$ ROLANDINO DE PÁDUA. Cronica in factis et circa facta Marchie trivixane....

${ }^{54}$ TRATADO...

${ }^{55}$ INOCÊNCIO III. Veri pacifici vestigia....
} 
A muttita era um imposto direto e extraordinário coletado quando a cidade precisava financiar os cavalos com as quais armaria seus cavaleiros. Armar os cavaleiros era algo que beneficiava a toda a comunidade, porque os cavaleiros a defendiam; por isso mesmo a muttita indenizava os cavaleiros que perdiam seus cavalos em batalha (o cavalo é de propriedade do cavaleiro, não da comuna; esta apenas o "arrenda", junto com o cavaleiro, que recebe privilégios em troca de seu serviço), bem como os mantinha em tempos de paz. Mas vemos que o arbítrio papal estabelece os "entes" em prol dos quais a muttita e o serviço que ela custeia devem se reverter: são todas unidades universais (algumas grafadas, inclusive, com maiúscula). O poder público do papa ainda estabeleceu as condições em que o imposto devia ser arrecadado (o povo perusino havia entrado em guerra civil justamente por causa das divergências que a falta de clareza nos critério de cobrança e repartição da muttita gerava): havia um juramento a ser prestado pelos coletores (um juramento que não pode ser privatizado) e era preciso, antes de coletar, respeitar o tesouro comum, para que não se onerassem injustamente os cidadãos.

De alguma forma, contudo, a dimensão terrena do bem comum deixava de ser o fim último da política para se tornar um meio de se alcançar o fim verdadeiro que era a salvação; a conservação do mundo político terreno deixou de ser a própria finalidade da política, como em Cícero, para se tornar um fim intermediário, uma etapa, apenas, em vista de outra finalidade maior. A partir de Agostinho, tanto o fundamento teológico quanto o antropológico da política estavam voltados para essa nova finalidade. Fazer um bom governo, preservar a comunidade política e buscar o bem comum - em seus dois níveis, terreno e transcendental, por assim dizer tornaram-se as condições de legitimidade da política, os critérios de sua validade. Mas não que Agostinho tenha se desprendido de Cícero; não é que, para ele, o político terreno fosse desprezível e só importasse o político transcendental. Em Agostinho a salvação era um bem maior, mas, ainda assim, era um bem comum, cuja primeira etapa de efetivação estava na terra. Por isso o bom ordenamento político material era condição sine qua non para a salvação espiritual. À Cidade de Deus, enfim, precedia uma Cidade dos Homens, de maneira que para os medievais continuava imprescindível, como para os romanos, forjar uma política capaz de pacificar os conflitos decorrentes da pluralidade humana.

\section{Considerações finais}

Neste texto, procuramos fazer um exercício de alteridade, de compreensão de outras formas de existência do político e de exercício da política, que não as nossas, aquelas inauguradas na Modernidade. Objetivamos propor algumas maneiras de compreender o que sejam a sociedade, o político e a política na Idade Média por meio da análise de dois conceitos-chave presentes nas fontes medievais: as ideias de comunidade e de bem comum.

Aqui amarramos, finalmente, o ponto que deixamos desatado na seção 1: a communitas é política porque sua finalidade, o bonum commune (ou a salutem), é política. Essa finalidade se inscreve no político porque mesmo a salvação visa a um benefício (e por isso é um bem) revertido em prol da própria comunidade, de toda 
ela. E ela é política no sentido de que sua mera existência - ou melhor: a busca por ela - racionaliza o corpo político.

Se, no pensamento arendtiano, a coisa política é aquela que não está na esfera privada, mas na pública, e tem finalidade nela mesma, na reprodução do próprio corpo político e da esfera pública, está atendido o seu critério para que a noção baixo-medieval de bem comum e salvação sejam políticas e, consequentemente, a comunidade também o seja: ambos, bem comum e salvação, são metas públicas (que em autores como Agostinho tornam-se quase sinônimos), cujo alcance depende de todos os indivíduos componentes da coletividade. Mas Arendt parece ter se ressentido de que os medievais, com Agostinho, tenham transformado esse fim não em um objetivo último do político, como entre os romanos, mas num "trampolim" para outra meta tida como superior, esta sim se inscrevendo no campo do privado: a salvação. Afinal, na leitura de Arendt fez de Agostinho, diz respeito a cada indivíduo em sua singularidade; é a salvação da alma, é o indivíduo que importa. Nesta leitura é que a autora parece ter baseado a sua impressão de que no medievo nasceu a anomalia da esfera híbrida do social, mistura do privado com o público, que apagava as fronteiras entre ambos e corrompia o político e a política ${ }^{56}$. Para ela, se a finalidade da política medieval era individualista, ela só podia se orientar por uma estrutura privada de poder - o feudo, uma "grande família" - que exercia não a política, mas a dominação, o despotismo.

Se seguimos o argumento arendtiano, concluímos que não houve poder público ou esfera pública na Idade Média. Porém, seguindo o insight de Morsel, o que quisemos mostrar aqui é que a dimensão desse poder e dessa esfera se mantiveram, ainda que com transformações, e a permanência dos sentidos de civitas, bonum commune e communitas comprovam isso. Assim como os romanos, cuja política Arendt louvou, os medievais também conheceram e praticaram noções de pluralidade, de corpo político e de conflito ordenado (ou seja: de política e de governo), como mostram o tratado de paz feito em Assis, a bula de Inocêncio III e as crônicas de Iacopo de Varazze, Salimbene de Parma, Bonvesin de la Riva e Rolandino de Pádua. Para enxergar e compreender tais noções, contudo, é preciso que adaptemos o nosso olhar e elaboremos outros métodos de abordagem, outras técnicas hermenêuticas, outras teorias do que possam ser cada um desses objetos de investigação - como fez, por exemplo, Pierre Clastres, em suas pesquisas antropológicas.

\section{$\operatorname{soc} 2$}

${ }^{56}$ ARENDT, A condição humana... p. 38. 


\section{RESUMO}

Este artigo versa sobre o bem comum $e$ a comunidade no pensamento político medieval. O problema investigado é: como pensar a política numa sociedade sem um estado de tipo moderno? A hipótese da qual parte é a de que, diante dessa ausência, é preciso pensar a política em espaços não-estatais. Metodologicamente, afilia-se a uma História Conceitual do Político, debruçando-se sobre bulas, histórias, crônicas e tratados da época, cujos conceitos-chave são analisados. $\mathrm{O}$ objetivo é estabelecer bases conceituais para que se entenda a política medieval.

Palavras Chave: Política; Comunidade; Bem comum.

Artigo recebido em 18 abr. 2018.

Aprovado em 02 jul. 2018.

\section{ABSTRACT}

This article analyzes the common good and the idea of community in the medieval political thought. The matter to be investigated is: how to think politics in a society without a modern shaped state? The hypothesis is that in a society amongst this absence, it is necessary to think politics in non-state spaces. Methodologically, it is affiliated with a Conceptual History of Politics, looking on bulls, histories, chronics and treaties from that time. The goal is to establish conceptual bases so Medieval Politics can be better understood.

Keywords: Politics; Community; Common good. 